\title{
Effect of organic acids and essential oils on growth performance of commercial broiler in Bangladesh
}

\section{F. Islam ${ }^{\mathrm{a}}$, A. Majumder ${ }^{\mathrm{b}}$, A. Khatun ${ }^{\mathrm{b}}$ and M. S. Hossain ${ }^{\mathrm{c}}$}

aPoultry Consultant, A. K. Fish and Poultry Feed (Pvt.) Ltd., Kabirhat Road, Sirajpur, Bashurhat, Companigonj, Noakhali

${ }^{b}$ Department of Poultry Science, Bangladesh Agricultural University, Mymensingh 2202

cDepartment of Animal Breeding and Genetics, Bangladesh Agricultural University, Mymensingh 2202

$\bowtie$ farukkrishibid@gmail.com (Islam, F.), \& +88-018-39979152, Published: 25 May 2016.

\begin{abstract}
A total of 990 Cobb 500 straight run day old chicks were housed on March 18, 2016 and reared up to April 1, 2016 to examine the effect of organic acids and essential oils on growth performances and health status at a village farm in Companigonj upazila under the district of Noakhali in Bangladesh. Body weight at 7 days of age and at 14 days of age were significantly higher for feed type two (159.99 $\pm 0.16 \mathrm{~g}$ and $442.22 \pm 0.38 \mathrm{~g}$, respectively). Average daily body weight gain at 8 to 14 days of age in feed type one was higher $(41.09 \pm 0.03 \mathrm{~g} / \mathrm{d} / \mathrm{b})$ than feed type two but higher feed conversion was recorded with feed type two (1.141) for the broiler birds of 14 days old. This study demonstrated that organic acids and essential oils supplementation in the broiler ration (feed type two) might help to increase the body weight and decrease mortality rate up to age of 14 days. It also revealed that feed to meat conversion might be increased through organic acids and essential oils supplementation. But to learn about the individual effect of organic acids preparation or essential oils preparations further study designing two feed types with similar nutrition in which one will be supplemented with organic acids and the other one with essential oils supplementation would be worthwhile.
\end{abstract}

Key Words: Organic acids, Essential oils, Commercial broiler and Bangladesh

Cite article: Islam, F., Majumder, A., Khatun, A. \& Hossain, M. S. (2016). Effect of organic acids and essential oils on growth performance of commercial broiler in Bangladesh. Journal of Bioscience and Agriculture Research, 08(02), 754-758.

Article distributed under terms of a Creative Common Attribution 4.0 International License.

\section{Introduction}

Broiler industry in Bangladesh generated employment and supplying complete protein to the poor in a cheaper rate compare to other animal protein sources. Poultry industry contributed $18.60 \%$ of total agricultural contribution in gross domestic production in Bangladesh (Khaled, 2014). But in recent day's use of antibiotics in the commercial broiler production arising the risks of human health. Essential oils are used as natural alternatives for replacing antibiotic growth promoters (AGPs) in poultry feed because these have antimicrobial, antifungal, antiparasitic, and antiviral properties (Krishan and Narang, 2014). The European Union (EU) in 2006 banned antibiotic growth promoters to be used as additives in animal nutrition for the growing concern over the transmission and 
proliferation of resistant bacteria via the food chain. So, to minimize the risk of spreading antibiotic resistance from animals to humans via food chain the need for alternative strategies aroused and the alternative might be organic acids and their salts (Adil et al., 2011). Organic acids can be used as alternatives to antibiotics and these materials have growth promoting properties (Patten and Waldroup 1988). Organic acid supplementation improve digestibility of protein and minerals like calcium, phosphorus, magnesium and zinc and decrease colonization of pathogens and production of toxic metabolites and also serve as substrates in the intermediary metabolism (Kirchgessner and Roth 1988). Essential oils are a mixture of various compounds (mainly terpenes and terpene derivatives) (Başer and Demirci, 2007) which obtained from plants are concentrated hydrophobic liquids contains volatile aromatic compounds (Mathe, 2009). The present research work was done with the objectives to observe the effect of organic acids and essential oils on health and growth performances of commercial broiler chicken.

\section{Materials and Methods}

A total of 990 Cobb 500 straight run day old chicks were housed on March 18, 2016 and reared up to April 1, 2016 to examine the effect of organic acids and essential oils at a village farm in Companigonj upazila under the district of Noakhali in Bangladesh. Average day old body weight of chicks was 31.25 g per bird and their parent stock's age was 26 weeks. An open side gable type broiler house with pacca floor and corrugated iron sheet made roof was used. Rice husk was used as litter materials. From the very first day, day old chicks were divided into two part in the same house. For feed type one a total of 500 day old chicks and for feed type two 490 day old chicks were housed. Individual weight was taken at 7 days of age and at 14 days of age. Same brooding and rearing environment was provided for both groups of birds. Two types of feed were used in two different groups of birds from the very first day and continued up to 14 days of age. Electric brooders were used. Two vaccines like Newcastle and Gumboro were administered as per manufacturer's instructions. Same management was practiced in both part of the house. Only feed formulation was different. For part one feed type one and for part two feed type two were used.

\section{Feed types were like below:}

\begin{tabular}{|l|l|l|}
\hline Parameters & Feed type one & Feed type two \\
\hline Metabolizable energy & $3037 \mathrm{kcal}$ & $3037 \mathrm{kcal}$ \\
\hline Crude Protein & $22.81 \%$ & $22.81 \%$ \\
\hline Crude fat & $6.08 \%$ & $6.08 \%$ \\
\hline Crude fibre & $3.43 \%$ & $3.43 \%$ \\
\hline Calcium & $1.13 \%$ & $1.13 \%$ \\
\hline Phophorus & $0.77 \%$ & $0.77 \%$ \\
\hline Lysine & $1.39 \%$ & $1.39 \%$ \\
\hline Metrhionine & $0.54 \%$ & $0.54 \%$ \\
\hline Sodium & $0.18 \%$ & $0.18 \%$ \\
\hline Chloride & $0.19 \%$ & $0.19 \%$ \\
\hline Methionine and Cystine & $0.69 \%$ & $0.69 \%$ \\
\hline Organic acids and salts & Did not use & Used \\
\hline Essential oils and minerals & Did not use & Used \\
\hline
\end{tabular}

Nutritive value shown in the table was calculated for each of $100 \mathrm{~kg}$ feed.

\section{Major ingredients used to formulate feed used in the study}

Maize, Wheat flour, Rice polish, Soybean meals and oils, Meat \& Bone meal, Limestone and Dicalcium phosphate etc.

\section{Organic acids and essential oils used in the feed were as like as below}

Organic acids and salts: A powerful combination of organic acids like propionic and formic acid and their salts ammonium propionate and ammonium formiate. Dose used: $2 \mathrm{~kg}$ per ton of feed. 
Essential oils and minerals: Essentials natural oils premix for poultry. Ingredients: Essential oils: $250 \mathrm{mg} / \mathrm{kg}$, binder (silicic acid precipitated) $333.333 \mathrm{mg} / \mathrm{kg}$, phosphorus $540 \mathrm{mg} / \mathrm{kg}$, magnesium 185 $\mathrm{mg} / \mathrm{kg}$, sulphur $216 \mathrm{mg} / \mathrm{kg}$. Dose used: $1 \mathrm{~kg}$ per ton of feed.

\section{Experimental design and data analysis}

The numbers of observations in different traits were unequal. So, the statistical design of the study was unbalanced factorial in nature. For having the descriptive statistics of traits like body weight at 7 days of age (BWT1) and body weight at 14 days of age (BWT2), average daily body weight gain at 1 to 7 days (ADG1) and at 8 to 14 days (ADG2) of age, SAS (2006) software was used. However, the least square means were obtained in SAS GLM using the following generalized linear model:

$$
\begin{aligned}
& Y_{i}=\mu+B_{i}+e_{i} \\
& \begin{array}{l}
\text { Where, } Y_{i}=\text { Dependent variables (BWT1, BWT2, ADG1 and ADG2) } \\
\mu=\text { Overall population mean for any of the said trait; } \\
\quad B_{i}=\text { Effect of ithfeed type (where } i=1 \text {-feed type one and 2- feed type two) } \\
\quad e_{i}=\text { Random residual error associated with } Y_{i} \text { observation }
\end{array}
\end{aligned}
$$

\section{Results and Discussion}

\section{Body weight and ADG at 1 to 7 days}

Body weight at 7 days of age was significantly higher for feed type two $(159.99 \pm 0.16 \mathrm{~g})$ than feed type one $(150.30 \pm 0.18 \mathrm{~g})$. Similarly, higher body weight in chickens supplemented of citric acid than the control group were reported (Kopecky et al., 2012; Chowdhury et al., 2009). At the present study we found higher average daily body weight gain for the birds fed feed with organic acids and essential oils supplementations at day 1 to day 7. Moreover, Khattak et al. (2014) observed, the body weight gain with positive effects on feed to gain ratio, when a blend of essential oils from basil, caraway, laurel, lemon, oregano, sage, tea and thyme were added in a diet meeting the nutrient requirements of broilers.

Table 01. Effect of organic acids and essential oils on body weight at the age of one week, body weight at the age of two week, average daily gain at the age of one week and average daily gain at the age of two weeks

\begin{tabular}{|l|l|l|l|}
\hline Traits & Feed type one & Feed type two & LS \\
\hline Body weight at 7 days of age & $150.30 \pm 0.18 \mathrm{~g}$ & $159.99 \pm 0.16 \mathrm{~g}$ & $* * *$ \\
\hline ADG at 1 to 7 days of age & $16.95 \pm 0.03 \mathrm{~g} / \mathrm{d} / \mathrm{b}$ & $18.34 \pm 0.02 \mathrm{~g} / \mathrm{d} / \mathrm{b}$ & $* * *$ \\
\hline Body weight at 14 days of age & $437.94 \pm 0.08 \mathrm{~g}$ & $442.22 \pm 0.38 \mathrm{~g}$ & $* * *$ \\
\hline ADG at 8 to 14 days of age & $41.09 \pm 0.03 \mathrm{~g} / \mathrm{d} / \mathrm{b}$ & $40.32 \pm 0.06 \mathrm{~g} / \mathrm{d} / \mathrm{b}$ & $* * *$ \\
\hline
\end{tabular}

LS= Level of Significance and ${ }^{* * *}$ significance at lower than $0.1 \%$., $\mathrm{g} / \mathrm{d} / \mathrm{b}=\mathrm{gram} / \mathrm{day} / \mathrm{bird}$.

\section{Body weight at 14 days of age and ADG at 8 to 14:}

Body weight at 14 days of age was significantly affected by the feed type. In case of feed type two higher (442.22 $\pm 0.38 \mathrm{~g}$ ) body weight at 14 days of age were recorded (Table 01$)$. However, Kopecky et al. (2012) found significant increase in average body weight $(\mathrm{P}<0.05)$ in 21 and 28 day of fattening when citric acid supplementation was done in the broiler diet. Average daily body weight gain at 8 to 14 days of age was significantly affected by feed type. Diet supplemented with organic acids and essential oils showed lower ADG than feed type one $(41.09 \pm 0.03 \mathrm{~g} / \mathrm{d} / \mathrm{b})$. Some researchers found essential oils as the growth stimulator in broiler birds (Cross et al., 2002; Bampidis et al., 2005).

\section{Feed conversion ratio}

Feed conversion was better in the diet supplemented with organic acids and essential oils. Higher feed conversion was recorded with feed type two (1.141) for the broiler birds of 14 days old. On the other 
hand difference for feed consumption per bird between acetic acid and citric acid supplemental diet was documented (Kopecky et al., 2012).

Table 02. Effect of organic acids and essential oils on feed conversion ratio and chicks mortality

\begin{tabular}{|l|l|l|}
\hline Traits & Feed type one & Feed type two \\
\hline Total live body weight at 14 days of age & $201.06 \mathrm{~kg}$ & $212.27 \mathrm{~kg}$ \\
\hline Feed consumption up to 14 days of age & $242.67 \mathrm{~kg}$ & $242.21 \mathrm{~kg}$ \\
\hline FCR & 1.206 & 1.141 \\
\hline Chicks survive up to 14 days of age & $460 \mathrm{pc}$ & $480 \mathrm{pc}$ \\
\hline Mortality up to 14 days of age & $8.00 \%$ & $2.04 \%$ \\
\hline
\end{tabular}

\section{Mortality}

Mortality rate was highly significantly affected by the feed type. Feed with organic acids and essentials oils supplementation reduced the mortality rate $(2.04 \%)$. Similar observation was reported by Kopecky et al. (2012) for the diet supplemented with organic acids. On the other hand Krishan and Narang (2014) found beneficial effects of essential oils include appetite stimulation, improvement of enzyme secretion related to food digestion, and immune response activation.

\section{Conclusion}

In conclusion, this study demonstrated that organic acids and essential oils supplementation in the broiler ration might help to increase the body weight and decrease mortality rate up to age of 14 days. It also revealed that feed to meat conversion might be increased through organic acids and essential oils supplementation. But to learn about the individual effect of organic acids preparation or essential oils preparations further study designing two feed types with similar nutrition in which one will be supplemented with organic acids and the other one with essential oils supplementation would be worthwhile.

\section{Acknowledgements}

We thankfully acknowledge the contribution of Mr. Dulal Majumder, commercial broiler farmer, Sirajpur, Bashurhat, Noakhali and Mr. Abul Kalam, Managing Director, A. K. Fish and Poultry Feed (Pvt.) Ltd., Kabirhat Road, Sirajpur, Bashurhat, Companigonj, Noakhali for their spontaneous support to carry out the experiment.

\section{References}

[1]. Adil, S., Banday, M. T., Bhat, G. A., Qureshi, S. D. \& Wani, S. A. (2011). Effect of supplemental organic acids on growth performance and gut microbial population of broiler chicken. Livestock Research for Rural Development, 23.

[2]. Bampidis, V. A., Christodoulou, V., Florou-Paneri, P., Christaki, E., Chatzopoulou, P. S., Tsiligianni, T. \& Spais, A. B. (2005). Effect of dietary dried oregano leaves on growth performance, carcase characteristics and serum cholesterol of female early maturing turkeys. British Journal of Poultry Science, 46, 595-601. http://dx.doi.org/10.1080/00071660500256057

[3]. Başer, K. H. C. \& Demirci, F. (2007). Chemistry of Essential Oils. In: Flavours and Fragrances: Chemistry, Bioprocessing and Sustainability, edited by Berger RG. New York: Springer; 2007. Pp. 43-86.

[4]. Chowdhury, R., Islam, K. M., Khan, M. J., Karim, M. R., Haque, M. N., Khatun, M. \& Pesti, G. M. (2009). Effect of citric acid, avilamycin and their combination on theperformance, tibia ash and immune status of broilers. Poultry Science, 88, 1616-1622.

http://dx.doi.org/10.3382/ps.2009-00119 
[5]. Cross, D. E., Acamovic, T., Deans, S. G. \& Cdevitt, R. M. (2002). The effects of dietary inclusion of herbs and their volatile oils on the performance of growing chickens. British Journal of Poultry Science, 43, 33-35. http://dx.doi.org/10.1080/000716602762388536

[6]. Khaled, S. M. S. (2014). Poultry industry: Realities and prospects. The Financial Express, International Publication Limited. http://www.thefinancialexpress-bd.com, visited on 26 April, 2014.

[7]. Khattak, F., Ronchi, A., Castelli, P. \& Sparks, N. (2014). Effects of natural blend of essential oil on growth performance, blood biochemistry, cecal morphology, and carcass quality of broiler chickens. Poultry science, 93, 132-137. http://dx.doi.org/10.3382/ps.2013-03387

[8]. Kirchgessner, M. \& Roth, F. X. (1988). Ergotrope effekte durch organische sauren in der fekelaufzucht und schweinemast. Ubersichten zur tiererenährung, 16, 93-108.

[9]. Kopecký, J., Hrncar, C. \& Weis, J. (2012). Effect of Organic Acids Supplement on Performance of Broiler Chickens. Scientific Papers: Animal Sciences and Biotechnologies, 45 (1).

[10]. Krishan, G. \& Narang, A. (2014). Use of essential oils in poultry nutrition, A new approach Journal of Advanced Veterinary and Animal Research, 1(4), 156-162.

[11]. Mathe, A. (2009). Essential oils-biochemistry, production and utilisation. In: Phytogenics in Animal Nutrition, Natural Concepts to Optimize Gut Health and Performance, edited by Steiner T. Nottingham University Press, 2009. pp. 1-18.

[12]. Patten, J. D. \& Waldroup, P. W. (1988). Use of organic acids in broiler diets. Poultry Science, 67, 1178-1182. http://dx.doi.org/10.3382/ps.0671178

[13]. SAS (2006). SAS Institute Inc., SAS Campus Drive, Cary, North Carolina 27513, USA. 